\title{
Influence of organic matter and climatic factors on the harpacticoid copepod (Crustacea) population from the well sorted fine sands of Banyuls Bay
}

\author{
J. Y. Bodiou, D. Delille \& L. Tito de Morais \\ Laboratoire Arago, Université P. et M. Curie, CNRS URA 117; F-66650 Banyuls-sur-mer
}

\begin{abstract}
The authors investigated the development of the harpacticoid copepod population in relation to the variations in organic matter and meteorology. Sediment sampling was performed over a 2-year period in the shallow waters ( $3 \mathrm{~m}$ deep) of Banyuls Bay (Western Mediterranean). Each year presents two distinct periods: winter to early spring, and from late spring until fall. During the first period of the annual cycle, the organic carbon and nitrogen cycles are fairly dissociated; the quantity of copepods appears to be dependent upon the climatic and physical conditions. During the second period, the climatic conditions are very similar from year to year, without heavy rains or strong storms, and the values observed both for the organic matter and the copepod population are also similar. The hypothesis is proposed that organic matter can be considered a limiting factor to population increase.
\end{abstract}

\section{INTRODUCTION}

Numerous works describe the seasonal variations in meiofaunal populations of sublittoral soft bottoms (Coull, 1970; Skoolmun \& Gerlach, 1971; Warwick \& Buchanan, 1971; Dinet, 1972; Nyholm \& Olsson, 1973; Bovée \& Soyer, 1974; Coull \& Vernberg, 1975; Juario, 1975; Nodot, 1978; Coull \& Fleeger, 1977; Hicks, 1977; Bell, 1979; Dinet et al., 1982; Boucher, 1983; Coull, 1985; Huys et al., 1986). Correlation analyses between seasonal variations of meiofauna and available trophic resources are scarcer: Bovée (1981), Rudnick et al. (1985) regarding organic matter; Montagna et al. (1983) and Bouvy (1985) regarding primary and bacterial production. Despite the fact that nematodes generally predominate in meiofaunal populations, harpacticoid copepods can be largely responsible for seasonal variations (Witte \& Ziljstra, 1984; Rudnick et al., 1985). Recent experimental studies indicate that copepods react more strongly than nematodes to organic enrichment of the sediment (Hockin, 1983; Gee et al., 1985; Moore \& Pearson, 1986). The present study succeeds previous works on the harpacticoid copepods of the fine sands of Banyuls Bay (Soyer, 1970; Bodiou \& Chardy, 1973; Bodiou, 1975; Bodiou, 1980). The faunistic variations of the harpacticoid population were investigated over 2 years in relation to the main organic variables and the climatic conditions. Interpretation of the field data is supported by a principal components analysis. 


\section{MATERIALS AND METHODS \\ Study area and sampling}

The study was performed in Banyuls Bay (Western Mediterranean: $3^{\circ} 08^{\prime} \mathrm{E}, 42^{\circ} 29^{\prime} \mathrm{N}$ ) (Fig. 1). The sampling area, at a depth of $3 \mathrm{~m}$, is at the upper edge of the well-sorted fine sand area, in a shallower zone than the one studied by Bodiou $(1975,1980)$, but with similar sediment characteristics. Sampling was performed twice a month, from January 1976 through January 1978. All sampling was made using SCUBA operated corers. Three cores were used for the faunistic studies ( $8 \mathrm{~cm}$ deep and $10 \mathrm{~cm}^{2}$ in area) and one for the

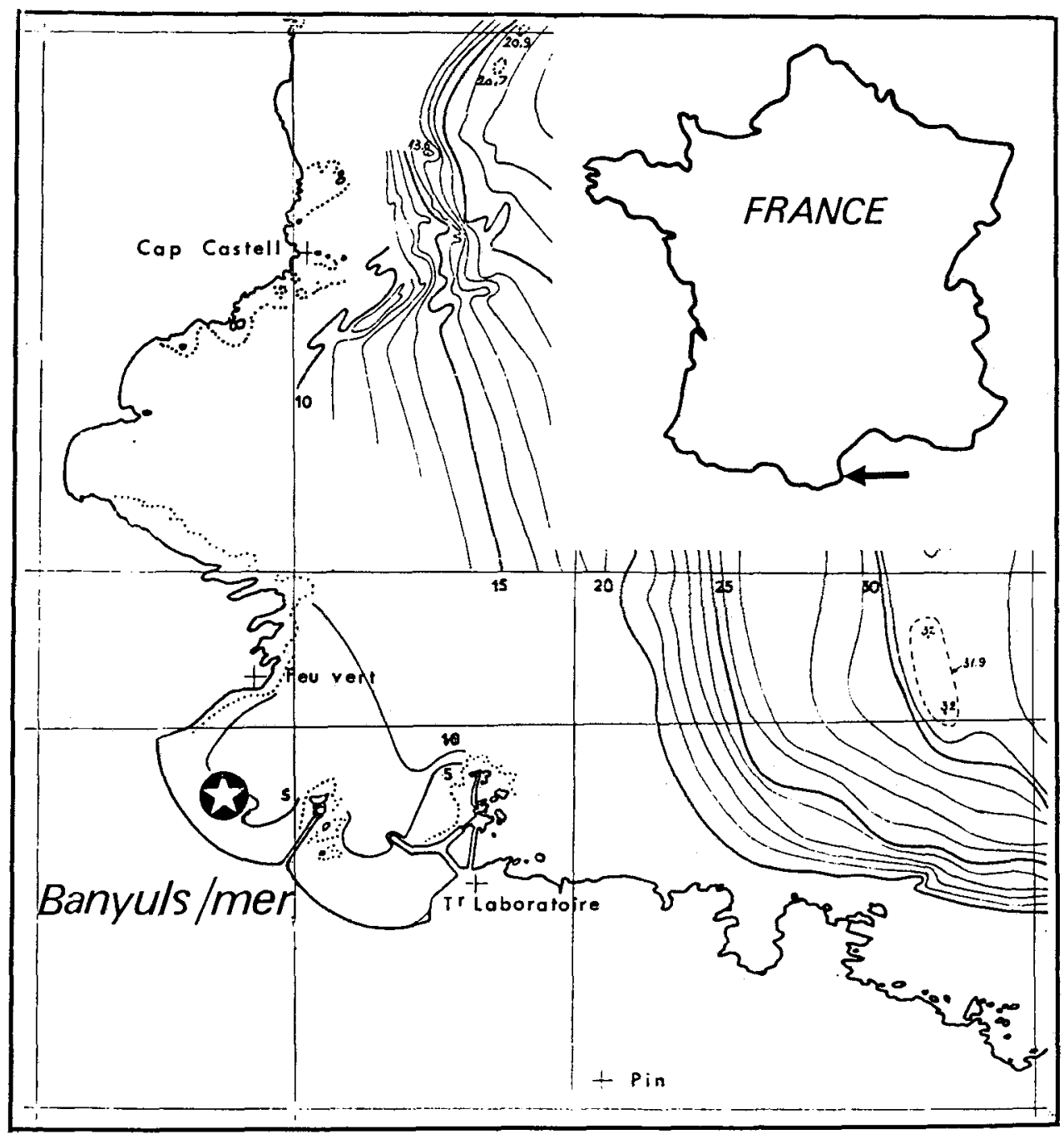

Fig. 1. Location of the sampling area. The zone is at a depth of $3 \mathrm{~m}$, in a sandy part of Banyuls Bay, France, in the western Mediterranean Sea $\left(3^{\circ} 08^{\prime} \mathrm{E}, 42^{\circ} 29^{\prime} \mathrm{N}\right)$ 
sediment analyses $\left(8 \mathrm{~cm}\right.$ deep and about $20 \mathrm{~cm}^{2}$ in area). The harpacticoid copepods were sorted under a dissecting microscope after concentration and colouration with Rose Bengale.

\section{Chemical analysis}

Carbon was measured according to the LECO technique (IR-212 analyser). The organic carbon content (CORG in the figures) is obtained using a dry sediment sample previously decarbonated by hot orthophosphoric acid (1M). The value given for inorganic carbon (MC) is obtained by calculating the difference between the total carbon measured on raw dry sediment and the organic carbon measured on dry decarbonated sediment.

All nitrogen analyses were performed using the Kjeldahl method. A Buchi apparatus was used for total nitrogen determination. The mineralization and vapour release were carried out in the same container. The distillate was then titrated using N/100 soda. Ammonia value was obtained in the same way, without prior mineralization of the sample. Nitrates and nitrites values were obtained using a colorimetric technique (Technicon apparatus), after extraction by a Normal $\mathrm{KCl}$ solution. The organic nitrogen value (NORG) was obtained by calculating the difference between the total nitrogen and the sum of ammonia, nitrates and nitrites.

\section{Principal components analysis}

The principal components analysis provides a graphical representation of any set of $n$ heterogeneous variables in mutual correlation (Lebart et al., 1977; Fenelon, 1981). Each sample is defined by the density of benthic copepods and the quantities of organic carbon and organic nitrogen in the sediment.

\section{RESULTS}

\section{Meteorological conditions}

Winter and spring meteorological conditions in the sampling area were notably different in 1976 and 1977. East to South-East winds $\left(120\right.$ to $\left.190^{\circ}\right)$ of more than $5 \mathrm{~m} / \mathrm{s}$ lasting at least 2 days are shown in Figure 2. Such winds are the cause of a strong littoral swell in the bay (Razouls, 1971). In 1976, from February 1st to May 31st, 10 strong-wind periods were registered; during the same months in 1977 only 4 periods of strong winds were registered. The summer wind conditions were quite similar in 1976 and 1977.

\section{Quantitative evolution of harpacticoid copepods}

The quantities of copepods (Fig. 2) varied both in 1976 and 1977 following a cycle of 4 periods: minimum in late May and early June (point 1), maximum in late July and early August (point 2), minimum in late August and early September (point 3) and maximum in late October (point 4).

The years 1976 and 1977 showed similar changes in the population from late May to October (i.e. from point 1 to point 4): 2 peaks of maximum concentration separated by a 
sharp decline of the populations in August. Apart from this period, there was little similarity between 1976 and 1977 . Winter in 1976 showed low concentrations, descending to a minimum in late May (always less than 40 ind. $/ 10 \mathrm{~cm}^{2}$ ); on the other hand, winter in 1977 showed high concentrations (always more than 40 ind. $/ 10 \mathrm{~cm}^{2}$ ) from February to late May. The quantity of copepods declined sharply in November 1976 (from 120 to 20 ind. $/ 10 \mathrm{~cm}^{2}$ ); no such decline was observed in autumn 1977.

\section{Variations in the physical and chemical parameters}

The 2 years of sampling provided very similar results. In both 1976 and 1977, 4 maxima of organic carbon (CORG, Fig. 2) were observed (in January, May, September and November). In both 1976 and 1977, a high maximum value of inorganic carbon (MC, Fig. 2) was observed in March and April; two lower maxima were observed in August and September. With the exception of the increased values in autumn, the organic nitrogen content of the sediment (NORG, Fig. 2) was relatively stable during each of the 2 years.

\section{Data from the principal components analysis}

The first three factorial axes represent $84.3 \%$ of the total variance of the system $(35.3 \%, 29.6 \%$ and $19.4 \%$ respectively). The position of each variable and their absolute contribution to the total inertia of each of the first three axes are given in Table 1 , and represented in Figure $3(\mathrm{~A}, \mathrm{~B})$. Axis $\mathrm{I}$ is closely related $(\mathrm{r}=0.95)$ to the total concentration of copepods (QTOT). Axis II is in correlation $(\mathrm{r}=0.76)$ with organic carbon (CORG) and axis III ( $r=0.84)$ with organic nitrogen (NORG).

The analysis distinguishes between the spring samplings of the 2 years. In the spring of 1976, the samples from the period 3 March 1976 till 10 June 1976 (samples 5 to 11) were all gathered in the left zone of the factorial plan of axes I and II (Fig. $3 \mathrm{~A}$ ). This area corresponds to the samples of low copepod concentration. In the spring of 1977, the samples 31 to 36 (17 March 1977 till 25 May 1977) were spread out along the site of axis I, correlated to QTOT (Fig. 3A), reflecting the peaks in copepod population observed in this period. Samples 17 to 20 (high population peaks in 1976, from 3 September till 18 October) were in the right part of the factorial plan, correlated with high values of organic matter. From 27 October 1976 till 17 March 1977 (points 21 to 31), alternating positive/ negative peaks in copepod population and in organic carbon were apparent in Figure $3 \mathrm{~A}$.

\section{DISCUSSION}

\section{Sediment chemistry}

The sampling station has an average carbon value of $0.30 \%$ of D.W. Such low values are usual in this kind of sandy sediment (Delille, 1977), and they are higher than the values of carbon observed in the deeper sediments of the same area $(0.20 \%$ of D.W. at a depth of $15 \mathrm{~m}$ ) (Delille, unpubl. data). The values for the organic nitrogen content of the sediment are lower compared with those of the carbon content $(0.17 \%$ of D.W.). The C/N values observed are relatively high for a marine sediment (between 15 and 20). These high values are related to the terrestrial influence that differentiates the sampling area 


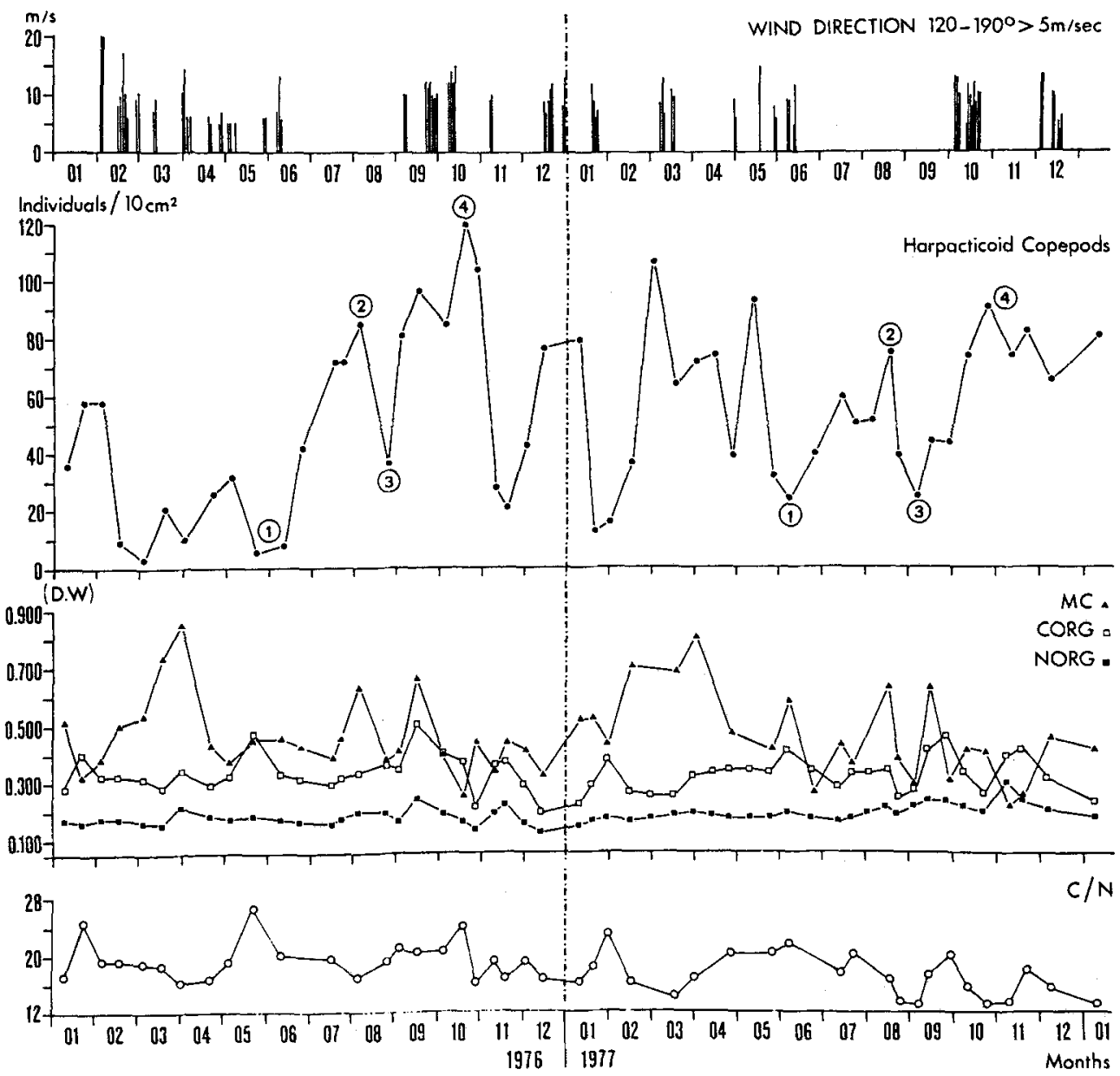

Fig. 2. Seasonal evolution of the harpacticoid copepod population and of the sediment organic content. Abbreviations used: $\mathrm{C} / \mathrm{N}=$ ratio between organic carbon and nitrogen; $\mathrm{CORG}=$ organic carbon content in $\%$ of $\mathrm{D}$. $\mathrm{W}$. sediment; $\mathrm{MC}=$ mineral carbon content in $\%$ of $\mathrm{D}$. $\mathrm{W}$. sediment; NORG $=$ organic nitrogen content in \% of $\mathrm{D} . \mathrm{W}$. sediment

from deeper zones. At $15 \mathrm{~m}$ below sea-level, despite a similar granulometry of the sediment, the $\mathrm{C} / \mathrm{N}$ values are under 12 and generally close to 8 (Delille, unpubl. data). These lower values are more usual in marine environments (Delille et al., 1979).

Organic nitrogen and carbon values are closely related (Table 1). Seasonal changes of these two parameters are relatively similar. However, some differences can be observed. The $\mathrm{C} / \mathrm{N}$ ratio depends both upon the origin of the organic matter (predominance of terrestrial or marine deposits), and upon differences in the level of degradation. The differences in $\mathrm{C} / \mathrm{N}$ ratios in 1976 and 1977 clearly indicate that the composition of the organic matter in the sediment was dissimilar during these two years. The spring situation and its organic nitrogen peak may be related to the increase of the benthic 
Table 1. Saturation values of the principal components analysis. - Correlation of paired variables. Multiple correlation coefficients between the variables and the first three factorial axes (QLT). Correlation coefficient between each variable and each of the three factorial axes (COR). - Relative contribution of each variable to the inertia of each.factorial axis (CTR). All values multiplied by 1000 . The critical values for single correlations are $\mathrm{t}(50.1)=0.273$ (at $\mathrm{P}=0.05)$ and $\mathrm{t}(50.1)=0.354($ at $\mathrm{P}=$ 0.01 ). The critical values for multiple correlation coefficients are $F(48.3)=0.386($ at $P=0.05$ ) and

$\mathrm{F}(48.3)=0.457($ at $\mathrm{P}=0.01)$. N.S. $=$ non significant ${ }^{*}=$ significant; $^{*}$ " = very significant

\begin{tabular}{|c|c|c|c|c|c|c|}
\hline & \multicolumn{6}{|c|}{ Correlation coefficient of paired variables } \\
\hline & CORG & NORG & & & QTOT & QLT \\
\hline CORG & 1000 & & & & & $955^{* *}$ \\
\hline NORG & $604^{*}$ & 1000 & & & & $966^{* *}$ \\
\hline $\mathrm{C} / \mathrm{N}$ & $634^{* *}$ & $-223 \mathrm{NS}$ & 100 & & & $832 * *$ \\
\hline \multirow[t]{3}{*}{ QTOT } & $-130 \mathrm{NS}$ & $29 \mathrm{NS}$ & -1 & & 1000 & $972 * *$ \\
\hline & \multicolumn{2}{|c|}{ 1st axis } & \multicolumn{2}{|c|}{ 2nd axis } & \multicolumn{2}{|c|}{3 rd axis } \\
\hline & COR & CTR & COR & CTR & COR & CTR \\
\hline CORG & $78 \mathrm{NS}$ & 32 & $760^{* *}$ & 367 & $117 \mathrm{NS}$ & 86 \\
\hline NORG & 2 NS & 1 & $126 \mathrm{NS}$ & 61 & $838^{* *}$ & 618 \\
\hline $\mathrm{C} / \mathrm{N}$ & $97 \mathrm{NS}$ & 39 & $516^{* *}$ & 250 & 219 NS & 161 \\
\hline QTOT & $955 *$ & 386 & $13 \mathrm{NS}$ & 6 & 3 NS & 2 \\
\hline
\end{tabular}

biomass. Recent works (Delille et al., 1990) indicate the existence of a bacterial bloom in spring in Banyuls Bay. As a result of bacterial mineralization, the organic carbon value decreases as the inorganic form increases. Nitrogen is, preferentially used in biosynthesis and shows little variation. Spring is the period of benthic recruitment for most mixobenthic forms (transitory meiofauna), and especially for the bivalve Spisula subtruncata. Such organisms may be of some importance in the nitrogen balance. Also, the shells influence the concentration of inorganic carbon.

The principal component analysis illustrates the major trends of the organic nitrogen and carbon as described above. Both values are correlated and are well-represented in the reduced factorial space. They induce slightly different behaviour of the samples in the factorial plan of axes II and III (Fig. 3B). The variations are greater along axis II than along axis III, indicating the higher variability of the values of organic carbon than those of organic nitrogen. On the other hand, the spring samples, 5 to 9 in 1976 (3 March till 4 May), and 32 to 36 in 1977 ( 1 April till 25 May) are spread out along axis III (related to organic nitrogen), and show little variation along axis II (organic carbon). The spring period is well differentiated from the rest of the year with regard to the variations in the organic matter parameters.

\section{Benthic copepod population}

In 1976 and 1977, the annual quantitative cycle of the copepod populations were similar in summer and autumn (points 1 to 4 in Fig. 2). During these periods of the year the atmospheric and physical conditions tend to be very stable. The littoral upper mass of water is above the thermocline, is temperate and undergoes few alterations (Jacques, 

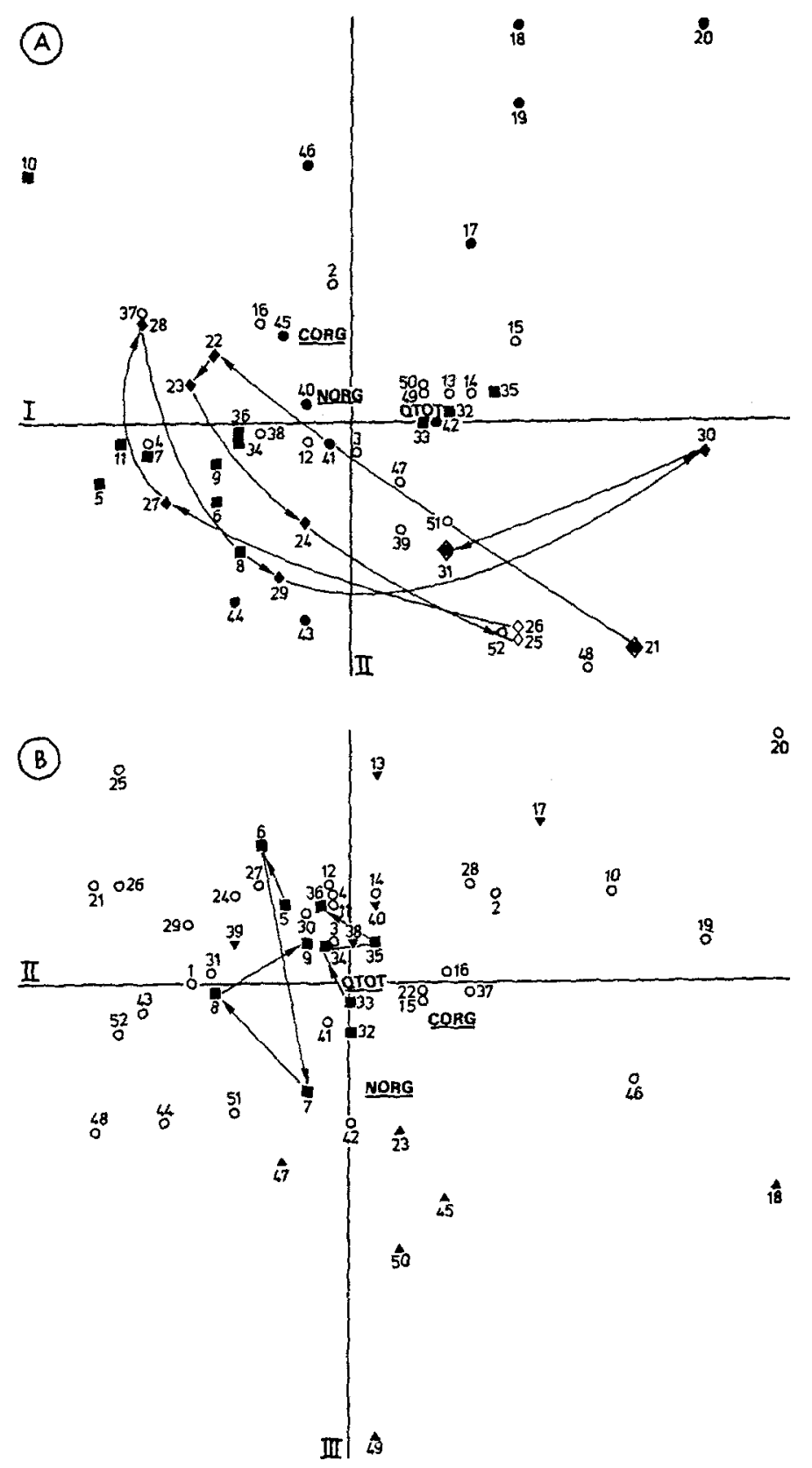

Fig. 3. Principal component analysis. Graphic representation of the variables and of the samples in the factorial space of the first three axes. The samples are numbered from 1 to 52 in chronological order from 08 January 1976 till 11 January 1978. A: Factorial plan of Axis I and II. B: Factorial plan of Axis II and III. - Autumn and winter samples in 1976/1977. Spring samples of both years. Summer and early autumn samples of both years. « Samples showing an organic nitrogen maximum preceding the faunistic peaks in autumn and winter in both years. $\checkmark$ Samples showing an organic nitrogen minimum preceding the faunistic peaks in summer in both years. QTOT $=$ total number of harpacticoid copepods per sample of $10 \mathrm{~cm}^{2}$; for other abbrev., see legend of Fig. 2 
1974). In contrast, the atmospheric physical conditions in winter and early spring may be quite different from one year to the next. Sediments are strongly disturbed by the waves induced by easterly storms (Emerson, 1989). Low salinity values related to heavy rains can also affect sediments, even in deeper areas 10 to $20 \mathrm{~m}$ deep (Bodiou \& Chardy, 1973). Bad weather conditions thus appear to influence the level of copepod concentration. The absence of windy periods in February 1977 can be related to the abundance of copepods observed during this period. In winter 1976, the benthic copepod population was subjected to more turbulent hydrodynamical conditions.

In the summer, the development and peak of copepod population are preceded by high values of $\mathrm{C} / \mathrm{N}$ ratio which could correspond to the degradation of terrestrial material brought about by the spring rainfalls, and to the microphytal development in the photic zone (Le Bouteiller, 1981). In the autumn, the double peak in copepods corresponds to high values of the $\mathrm{C} / \mathrm{N}$ ratio in 1976 and to low ones in 1977. Two points are to be emphasized: (1) the $\mathrm{C} / \mathrm{N}$ ratio increased in early September and mid October in 1976, but not until late September and mid November in 1977. (2) The first easterly storms were registered in September 1976, and not before October in 1977. The level of the C/N ratio appears to be related to the weather conditions, whereas increases in copepod populations can be connected to the presence of fragments of macrophytes in the sampling area. The presence of a large quota of phytophile copepods (e.g. Porcellidium viride, Bodiou, unpubl.) supports this hypothesis. Generally, the increase of harpacticoid copepod population is related to a decrease in the organic carbon in the sediment samples, and vice-versa (Fig. 2). More simply, we observe that there are connections between increases in the copepod population and decreases in the organic carbon available. When the available organic matter reaches a threshold value (the residual non-exploitable organic matter), the population decreases. At the same time, the organic carbon content of the sediment increases as the copepod population decreases. Although this study does not allow us to determine whether the relations between copepods and the organic matter are direct or indirect, it is apparent that the harpacticoid copepods are submitted to alternating periods of "abundant food/low or rare food". And it seems likely that these organisms depend more or less directly upon the trophic richness and stability of the sediments, and the presence of specific bacterial populations (McIntyre et al., 1970; Lasker et al., 1970; Marcotte, 1986). The entire copepod population studied here includes, throughout the year, different copepod species (Bodiou, 1980). They could verify the trophic resources hypothesis of Hicks \& Coull (1983) that emphasizes the existence of 3 trophic types: trophically adaptable species present throughout the year, abundant in winter in good weather conditions and scarce in bad conditions (e.g. Halectinosoma herdmani, Pseudobradya beduina, Stenhelia Delavalia normani). There are two types of trophically specialized species, depending upon food abundant only during certain periods: in this study, the species related to the benthic diatom bloom in late spring and early summer (e.g. Harpacticus flexus and Ameira parvula) or related to the arrival of macroalgae debris in autumn (e.g. Porcellidium viride) (Bodiou, 1980). Similar observations of two peaks and one minimum during the same period are described in muddy sediments by Bovée \& Soyer (1974) and Coull (1985). Jonczyk \& Radziejewska (1984) also describe 2 maxima peaks in late spring and October on the Baltic Polish coast. Other Mediterranean studies (cf. Dinet, 1972; Nodot, 1978) only describe a single major peak during a 12-month period. The location of our sampling 
area, in a shallow bay close to a rocky shore covered with algae broken away in summer, induces a diversification of the trophic sources that may complicate the population cycles in autumn.

In conclusion, the abundance of meiofauna, as studied here through the harpacticoid copepods, appears to be controlled by two main factors: (1) meteorological and climatic factors in bad weather conditions, and (2) available organic matter during the rest of the year. The influence of additional factors remains open for debate but nonetheless may be taken into account: predators and their exploitation of the copepod populations (see review in Hicks \& Coull, 1983; Morais \& Bodiou, 1984; Coull, 1985). All the parameters described in the present paper undergo changes in relation with the dynamics of bacteria in the sediment, and this appears to be a worthwhile direction for further work.

Acknowledgements. The authors wish to thank J. Mabit and G. Boyer for the in situ sampling, and Dr. J. Soyer for his constructive criticism.

\section{LITERATURE CITED}

Bell, S. S., 1979. Short- and long-term variation in a high marsh meiofauna community. - Estuar. coast. mar. Sci. 8, 331-350.

Bodiou, J. Y., 1975. Copépodes Harpacticoïdes des sables fins infralittoraux de Banyuls sur mer. I. Description de la communauté. - Vie Milieu 25, 313-330.

Bodiou, J. Y., 1980. Copépodes Harpacticoides (Crustacea) des sables fins infralittoraux de Banyuls sur mer. II. Variations saisonnières qualitatives du peuplement. - Vie Milieu 30, 269-274.

Bodiou, J. Y. \& Chardy, P., 1973. Analyse en composantes principales du cycle annuel d'un peuplement de copépodes harpacticoïdes des sables fins infralittoraux de Banyuls-sur-mer. Mar. Biol. 20, 27-34.

Boucher, G., 1983. Evolution du méiobenthos des sables fins infralittoraux de la baie de Morlaix de 1972 à 1982. - Oceanol. Acta (Nr. spéc.) 4, 33-37.

Bouvy, M., 1985. Rôle des microflores bactériennes dans les transferts d'énergie au sein d'une station intertidale subantarctique (Archipel de Kerguelen). Thèse, Univ. Claude Bernard, Lyon, $135 \mathrm{pp}$.

Bovée (de), F., 1981. Ecologie et dynamique des Nématodes d'une vase sublittorale (Banyuls sur mer). Thèse, Univ. P. \& M. Curie, Paris, 194 pp.

Bovée (de), F. \& Soyer, J., 1974. Cycle annuel quantitatif du méiobenthos des vases terrigènes côtières. Distribution verticale. - Vie Milieu 24, 141-157.

Coull, B. C., 1970. Shallow water meiobenthos of the Bermuda Platform. - Oecologia 4, 325-357.

Coull, B. C., 1985. Long-term variability of estuarine meiobenthos: an 11-year study. - Mar. Ecol. Prog. Ser. 24, 205-218.

Coull, B. C. \& Fleeger, J. W., 1977. Long-term temporal variation and community dynamics of meiobenthic copepods. - Ecology 58, 1136-1143.

Coull, B. C. \& Vermberg, W. B., 1975. Reproductive periodicity of meiobenthic copepods: seasonal or continuous? - Mar. Biol. 32, 289-293.

Delille, D., 1977. Contribution à l'étude du rôle des populations bactériennes dans les principaux cycles biologiques $(C, N, S$. P) établis en milieu sédimentaire subantarctique (archipel de Kerguelen). Thèse, Univ. Lyon I, $286 \mathrm{pp}$.

Delille, D., Gadel, F. \& Cahet, G., 1979. La matière organique dans les dépots de l'archipel de Kerguelen. Distribution spatiale et saisonnière. - Oceanol. acta 2, 181-194.

Delille, D., Guidi, L. D. \& Cahet, G., 1990. Temporal variations of benthic bacterial microflora of the Northwestern Mediterranean Continental Shelf and Slope. - Mar. Ecol. (In press).

Dinet, A., 1972. Etude écologique des variations quantitatives annuelles d'un peuplement de copépodes harpacticoïdes psammiques. - Tethys 4, 95-112.

Dinet, A., Nodot, C., Vitiello, P. \& Vivier M. H., 1982. Impact d'un effluent thermique sur une communauté de copépodes harpacticoïdes benthiques. - Téthys 10, 355-363. 
Emerson, C. W., 1989. Wind stress limitation of benthic secondary production in shallow, softsediment communities. - Mar. Ecol. Prog. Ser. 53, 65-77.

Fenelon, J. P., 1981. Qu'est-ce que l'analyse des données? Lefonen, Paris, 311 pp.

Gee, J. M., Warwick, R. M., Schaanning, M., Berge, J. A. \& Ambrose, W. G., 1985. Effects of organic enrichment on meiofaunal abundance and community structure in sublittoral soft sediments. $-\mathrm{J}$. exp. mar. Biol. Ecol. 91, 247-262.

Hicks, G. R. F., 1977. Species associations and seasonal population densities of marine phytal harpacticoid copepods from Cook Strait. - N. Z. N1. mar. Freshwater Res. 11, 621-643.

Hicks, G. R. F. \& Coull, B. C., 1983. The ecology of marine meiobenthic harpacticoid copepods. Oceanogr. mar. Biol. 21, 67-175.

Hockin, D. C., 1983. The effects of organic enrichment upon a community of meiobenthic harpacticoid copepods. - Mar. environ. Res. 10, 45-58.

Huys, R., Herman, R. L. \& Heip, C., 1986. Seasonal fluctuations in vertical distribution and breeding of a subtidal harpacticoid community in the Southern Bight, North Sea. - Neth. J. Sea Res. 20, 375-383.

Jacques, G., 1974. La thermocline dans l'écologie du phytoplancton. - Oceanis 1, 51-76.

Jonczyk, E. \& Radziejewska, T., 1984. Temporal changes in sand meiofauna of a southern Baltic beach. - Limnologica 15, 421-423.

Juario, J., 1975. Nematode species composition and seasonal fluctuation of a sublittoral meiofauna community in the German Bight. - Veröff. Inst. Meeresforsch. Bremerh. 15, 283-337.

Lasker, R., Wells, J. B. J. \& McIntyre, A. D., 1970. Growth, reproduction, respiration and carbon utilization of the sand-dwelling harpacticoid copepod, Asellopsis intermedia. - J. mar, biol. Ass. U. K. $50,147-160$.

Le Bouteiller, C., 1981. Biologie et reproduction d'une population d'amphipodes de Banyuls-surmer: Siphonocoetes dellavallei. Thèse, Univ. P. \& M. Curie, Paris, 115 pp.

Lebart, L., Morineau, A. \& Tabard, N., 1977. Techniques de la description statistique, méthodes et logiciels pour l'analyse des grands tableaux. Dunod, Paris, $350 \mathrm{pp}$.

McIntyre, A. D., Munro, A. S. L. \& Steele, J. H., 1970. Energy flow in a sand ecosystem. In: Marine food chains. Ed. by J. H. Steele. Oliver \& Boyd, Edinburgh, 19-31.

Marcotte, B. M., 1986. Sedimentary particle sizes and the ecological grain of food resources for meiobenthic copepods. - Estuar. coast. Shelf Sci. 23, 423-427.

Montagna, P. A., Coull, B. C., Herring, T. L. \& Dudley, B. W., 1983. The relationship between abundances of meiofauna and their suspected microbial food (Diatoms and Bacteria). - Estuar. coast. Shelf Sci. 17, 381-394.

Moore, C. G. \& Pearson, T. H., 1986. Response of a marine benthic copepod assemblage to organic enrichment. - Proc. 2nd Int. Conf. on Copepoda, Ottawa, Canada, 13-17 August 1984. Ed. by G. Schriever, H. K. Schminke \& C. T. Shih, National Museums of Canada, Ottawa, 369-373.

Morais, L. (Tito de) \& Bodiou, J. Y., 1984. Predation on meiofauna by juvenile fish in a western Mediterranean flatfish nursery ground. - Mar. Biol, 82, 209-215.

Nodot, C., 1978. Cycles bíologiques de quelques espèces de copépodes harpacticoïdes psammiques. - Tethys $8,241-248$.

Nyholm, K. G. \& Olssont I., 1973. Seasonal fluctuations of the meiobenthos in an estuary on the Swedish West Coast. - Zoon 1, 69-76.

Razouls, C., 1971. Données climatologiques de la région de Banyuls sur mer. Année 1969-1970. Vie Milieu 22, 425-435.

Rudnick, D. T., Elmgren, R. \& Frithsen, J. B., 1985. Meiofaunal prominence and benthic seasonality in a coastal marine ecosystem. - Oecologia 67, 157-168.

Skoolmun, P. \& Gerlach, S. A., 1971. Jahreszeitliche Fluktuationen der Nematodenfauna im Gezeitenbereich des Weser-Ästuars (Deutsche Bucht). - Veröff. Inst. Meeresforsch. Bremerh. 13, 119-138.

Soyer, J., 1970. Bionomie benthique du plateau continental de la côte catalane française. III. Les peuplements de Copépodes Harpacticoides (Crustacea). - Vie Milieu 21, 337-511.

Warwick, R. M. \& Buchanan, J. B., 1971. The meiofauna off the coast of Northumberland. II. Seasonal stability of the nematodes population. - J. mar. biol. Ass. U. K. 51, 355-362.

Witte, J. I. \& Zijlstra, J. J., 1984. The meiofauna of a tidal flat in the western part of the Wadden Sea and its role in the benthic ecosystem. - Mar. Ecol. Prog. Ser. 14, 129-138. 